\title{
Women at Work: Women Executives and Company Boards - the Case Study of Women Entrepreneurialism
}

\author{
Richmond Yaw Yeboah \\ Rural Enterprise Project, Ministry of Trade \& Industry, Ghana (National Project Coordinator)
}

\begin{abstract}
orporate Governance is the bedrock of a thriving enterprise development (Peter Drucker). The success or otherwise of every organization being it small, medium or large depends on the quality of its management and most importantly board membership (Jack Welch, 2013). The gender parity and deliberate policy to empower women not within the management structure but greater seats at the Board level goes a long way to radically promote affirmative action.The Federation of Indian SME Association (FISME, 2019) has indicated that the strength and forward march of the Commonwealth is contingent on giving more qualified women seat at the Boardroom. FISME goes on to emphasize that Companies in India with greater women representation at top management and Board level tend to experience high growth rate in profitability/bottomline. GBS-Africa at the 2nd Edition of the Intra Commonwealth SME Trade Forum held in Nairobi, Kenya dated May 28th-29th, 2019 confirmed that Companies in Africa with women at strategic positions tend to have positive growth rate.

Women Executives according to the estimate of Tony Ellumelu Foundation (2018) constitutes about 27\% of all positions in Organizations - Private and Public Sectors. This is not encouraging at all. To correct this imbalance, the Tony Ellumelu Foundation (TEF) is pushing for 'Africapitalism"' that will see more women as Entrepreneurs. Once women begin to own their own companies, then the point of getting more Women Executives and Board Members is being actualized.

The December 2017 and January 2017 Editions of Forbes Magazine posited that getting more women at work requires conscious capitalism and policy direction especially at the Public Sector. This has also been strongly supported by the United Nations Conference on Trade and Development (UNCTAD) 2019. It has the Document caption 'Policy Guide on Women and Youth Entrepreneurship'. The Executive Summary stipulates that once more women accede to the era of Entrepreneurialism then getting more women as Corporate Executives and Board Members is not difficult to achieve.

All indications point to the fact that to get Women at work in order to achieve Corporate Executive and Board representations, we need to promote "Intrapreneurship and Entrepreneurship". However, women must demonstrate enough readiness, capacity and merit-based competence toward the realization of this noble mission.

This Research work authored by my very self with the Technical Support from the Women Department of the Bono Regional Coordinating Council-Ghana under the Sustainable Livelihood and Transparent and Local Authorities (SLATLA) Project is geared towards; establishing the actual and latent market limitations on women careers, deliberate policies for corporate affirmative action mostly in the Public Sector, Succession Plan development for Women among others.
\end{abstract}


Keywords: Corporate Governance, bedrock, enterprise development, gender parity, deliberate policy, empower women, management structure, Board level, affirmative action. Federation of Indian SME Association, Commonwealth, Boardroom, Women representation, profitability/bottomline, Intra Commonwealth SME Trade Forum, strategic positions, Tony Ellumelu Foundation, Africapitalism, United Nations Conference on Trade and Development, Policy Guide on Women and Youth Entrepreneurship, Executive Summary, Entrepreneurialism, Intrapreneurship, merit-based competence, Technical Support, Sustainable Livelihood and Transparent and Local Authorities (SLATLA). 